\title{
NEEDLEWORK AND MORAL INSTRUCTION IN ENGLISH SEVENTEENTH-CENTURY HOUSEHOLDS: THE CASE OF REBECCA
}

\author{
by AMANDA PULLAN
}

\section{I} $\mathrm{n}$ the seventeenth-century household, in which biblically themed decor was fashionable, many needlework projects included images of female biblical characters. Rebecca was among the most frequently embroidered. ${ }^{1}$ In both Protestant and Catholic traditions, Rebecca's story, recorded in Genesis $24,{ }^{2}$ was perceived as especially pertinent to the household. Depictions of her story appeared in the sixteenth-century picture Bibles which were dedicated to, and circulated among, Protestant and Catholic audiences in parts of western and central Europe. ${ }^{3}$ Rebecca also featured in Erhard Schön's didactic illustrated woodcut, Zwölf Frawen des Alten Testaments (c.I530). ${ }^{4}$ Not all biblical stories

1 Ruth Geuter has catalogued 770 embroideries from multiple museum collections, which include depictions of 395 biblical stories; she has identified Rebecca as one of the more common subjects, with 3I pieces:V. R. Geuter, 'Women and Enbroidery in Seventeenth-Century Britain: The Social, Religious, and Political Meanings of Domestic Needlework' (Ph.D. thesis, University of Wales, 1996), 285. I have found an additional nine pieces with Rebecca, bringing the total to 40.

2 Gen. 24: 1-66 tells how Rebecca was chosen to be Isaac's wife. Isaac's father Abraham sent his servant, unnamed here but known as Eliezer (cf. Gen. 15:2), to find a wife for Isaac among his relatives. Eliezer asked God for a sign to help him make the selection. He then approached Rebecca at the well, and asked for water. She offered to draw water for his camels in addition, fulfilling the sign. Eliezer explained to Rebecca and her family God's providence in the event, and Rebecca returned with Eliezer to Canaan to be Isaac's wife.

3 Two of the most eminent sixteenth-century volumes of biblical illustrations were Gerard de Jode, Thesaunus Sacranum Historianum Veteris Testamenti (Antwerp, 1585); and Jean de Tournes, Quadrins Historiques de la Bible (Lyons, 1553). The first edition of de Tourne's Quadrins was dedicated to the 'Trereverente Dame, Janne de la Rochefocaud, Abbess de Nostre dame de Xaintes', which suggests an audience which was both female and Catholic. In addition to German and Italian editions, Quadrins was also translated into English by Peter Derendel and published in England as The true and lovely historike portreatures of the Holy Bible (1553): Alfred Cartier, ed., Bibliographic des éditions des de Toumes, imprimeurs lyonnais: Mise en ordre avec une introduction et des appendices par Marius Audin et une notice biographique par E. Vial, 2 vols (Paris, I937), 1: 348 .

4 This woodcut may have been produced as an accompanying illustration to Hans Sachs's Der Ehren spiegel der Zwölf Durchlewditigen Frawen des Alten Testaments (I530): Yvonne Bleyerveld, 'Chaste, Obedient, and Devout: Biblical Women as Patterns of 
involving female figures were included in these illustrated works, so the inclusion of her story suggests that Rebecca was perceived as a proper model for young women. Moreover, the absence of Rebecca from the large-scale tapestries which throughout the fourteenth to sixteenth centuries commonly depicted biblical scenes provides an important contrast to the popularity of her story in smaller-scale domestic needlework projects. ${ }^{s}$

According to my calculations, after Esther, Rebecca is one of the most common biblical characters to appear in the needlework of this period, and more than to per cent of extant biblical needlework pieces feature her. ${ }^{6}$ However, these depictions of her have not received due consideration. The popularity of Rebecca's story has been attributed to its focus on marriage and motherhood - states with which seventeenth-century women would identify. ${ }^{7}$ Hans Sachs's instructive poem Der Ehren spiegel der Zwölf Durchleuchtigen Frawen des Alten Testaments (I530), a 'Mirror' of virtues for women, suggested that it was Rebecca's virtue of obedience to her parents and Isaac that was to be emulated. ${ }^{8}$ However, these considerations do not adequately explain why the episode most frequently represented in needlework pieces is Rebecca's offer of water to Abraham's servant. It seems surprising that the emphasis was not on Rebecca meeting Isaac for the first time. ${ }^{9}$ What was it about the youthful Rebecca's offering water to Abraham's servant that resonated so strikingly in the seventeenth-century household and

Female Virtue in Netherlandish and German Graphic Art, ca. 1500-1750', Simiolus: Netherlands Quarterly for the History of Art 28 (2000-1), 219-50, at 225.

$s$ Susan Groag Bell, The Lost Tapestries of the City of Ladies: Christine de Pizan's Renaissance Legacy (Berkeley, CA, 2004), 52; Guy Delmarcel, Flemish Tapestry (Tielt, 1999), 18.

6 Using my updated version of Geuter's inventory, I have identified Rebecca's story on 24 embroidered objects (some objects depict more than one story, each of which I have counted separately according to Geuter's method), from eleven different collections.

7 Mary M. Brooks, English Embroideries of the Sixteenth and Seventeenth Centuries in the Collection of the Ashmolean Museum (London, 2004), 40; Tara Hamling, Decorating the 'Godly' Household: Religious Art in Post-Reformation Britain (New Haven, CT, and London, 2010), 209; Geuter, 'Women and Embroidery', 292.

8 A. von Keller, ed., Hans Sachs. Werke, 26 vols (Tübingen 1870-1908), I: 203-10, as quoted in Bleyerveld, 'Chaste, Obedient, and Devout', 225 n. 28.

1) Pieces which portray only this scene, Isaac meeting Rebecca, begin to appear in the eighteenth century: see London, Victoria and Albert Museum Collections, T.45-1937; T.122-1930. 
made this such a popular image in the repertoire of needlework for young girls?

This essay will examine these extant seventeenth-century needlework projects alongside contemporary texts to address this question. It will argue that while the figure of Rebecca offered a variety of lessons, the virtue of industry and the vice of vanity were the most significant associations with her story. The first section will show how, by depicting Rebecca pouring water for Eliezer at the well, her industry was being praised. The virtue of industry and a woman's readiness for marriage could be demonstrated through her own act of producing needlework. The second section will examine one specific piece in which Rebecca was interpreted typologically as the Virgin Mary. This portrayal of Rebecca as a Marian figure highlights her role in initiating sexual intimacy with Isaac and her identity as a future mother.

The importance of the well scene is crucial to understanding Rebecca's significance. In other visual representations from the period, namely sixteenth-century woodcuts, Rebecca is almost always pictured with a water jug in hand, even if another scene is being represented (Fig. I). ${ }^{10}$ This metonymic device alerts us to the importance of her act of giving water to Eliezer. In needlework, the frequency of occurrence of the scene is striking. Eighteen of the twenty-two pieces representing Rebecca feature her exchange with Eliezer at the well, and in most cases the scene is found on the front or top of cabinets, in areas of high visibility. These eighteen pieces all portray the well scene using similar iconography. The several elements which consistently appear together include a well or fountain, a woman holding a jug, a man (often stylized in the court dress of Charles I) and camels. The standard iconography suggests that women were well versed in the elements of Rebecca's encounter with Eliezer at the well.

On a general level, the multiple representations of the well scene speak to a societal preoccupation with finding a God-ordained match. Having the appearance of virtue was essential for young women hoping to marry. It was even more crucial for their families, who had, as Linda Pollock has so aptly described, 'the problem of transforming girls into the ideal of femininity depicted in the

10 De Jode's Thesaurus Sacrarum includes an image of Jacob receiving the blessing from his father with Rebecca in the background holding the water jug. 


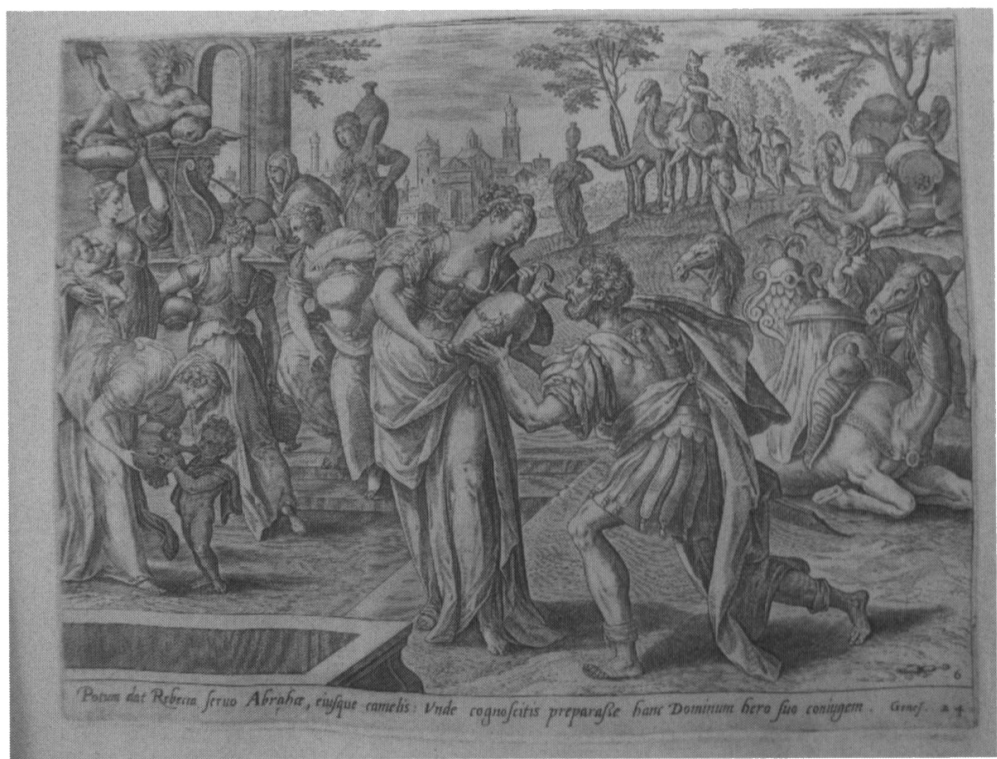

Fig. I: Rebecca and Eliezer, from Gerard De Jode, Thesaurus Sacrarum Historiarum Veteris Testamenti (Antwerp, 1585). Reproduced by permission of the Master and Fellows of St John's College, Cambridge.

scriptures'. ${ }^{11}$ The seriousness with which this responsibility was taken can be seen in the financial commitment undertaken by many families in funding their daughters' attendance at female academies, apparently with the sole objective of ensuring their eligibility for marriage. One embroidered cabinet with two scenes from the Rebecca narrative, the well scene and the meeting of Isaac and Rebecca, can be traced to a female academy in Hackney; an accompanying note records that the author's grandmother made it there before the outbreak of plague in $1665 .^{12}$ This may have been the 'Hackney school' which featured in William Wycherly's comedy, The Gentleman Dancing-Master, and which had the reputation of being a route by which women entered the marriage market. In Wycherly's play; Prud recounted how, by finding a 'Monsieur', it was evident that Hipp had 'not been to Hackney school for

"1 Linda Pollock, "'Teach Her to Live under Obedience": The Making of Women in the Upper Ranks of Early Modern England', Contintity and Change 4 (1989), $23 \mathrm{I}-58$, at 237 .

12 For a copy of the letter, see Brooks, English Embroideries, 40. 
nothing'. ${ }^{13}$ If one of the key roles of the educational institution was to prepare a young woman for the vocation of marriage and running a household, we can see why Rebecca would provide an appropriate model for this young pupil at Hackney.

However, Rebecca's significance was not merely as a portrayal of betrothal. The depiction of Rebecca serving water to Eliezer demonstrated industrious behaviour that signified readiness for marriage. It was the specific act of drawing water for Eliezer and his ten camels that cast Rebecca as one who was not idle but willing to work. Texts of the period associate industriousness with Rebecca. The Authorized Version (I6II) emphasizes her speed in executing the task. Rebecca's response to Eliezer, 'drink my lord', was followed by the comment 'and she hasted'. Two verses later, she 'hasted and emptied her pitcher into the trough and ranne again unto the well to draw water'. A third time, Eliezer pointed out to Laban, Rebecca's brother, how she had 'made haste and took down her pitcher from her shoulder'. ${ }^{4}$ A similar emphasis on Rebecca's industry is found in the Catholic Rheims-Douai translation. A note explains that 'the event sheweth such qualities and vertues in her, as were most agreable to the great charitie and hospitalitie dayly practized in Abrahams house, most convenient and necessairie for that family and good of manie'. ${ }^{15}$ Protestant and Catholic translations both suggest that Rebecca, by drawing water for the servant, showed the necessary industry for the proper running of a household.

Rebecca's industry is highlighted in the contemporary prescriptive literature as well. An important godly tract, The Golden Boke of Matrimonye (1542), a translation of the Swiss Protestant reformer Heinrich Bullinger's frequently reprinted Der christlich Eestand, explained that Rebecca was 'gentle, serviceable, lowly, given to labour, quick in her busyness, and loving toward strangers'. Beside this text, a note in the margin explained to the reader that these were 'the properties of a maid that should be [in a] chosen wyfe'. ${ }^{16}$

13 Willian Wycherly, The Gentleman Dancing-Master. A Comedy, As it is Acted By Their Majesties Servants (London, I693), Act I, Scene 1.

14 Gen. 24: 18-20 (AV).

is The Holy Bible faitly fully translated into English out of the authentical Latin, diligenty conferred the Hebrew, Greek, $\mathcal{E}$ other Editions in divers languages (Douai, I635), note on Gen. 24: 14 .

${ }_{16}$ H. Bullinger, The golde/n] boke of christen matrimonye moost necessary [and] profitable 
The author reiterated his approval of Rebecca's 'busyness' in serving Eliezer, commenting: 'When she commeth to the well she maketh no stop: nor bringeth a sorte of young fellowes with her, nether standeth she gasying and wondering upon the strange man, but quickly and straight goeth she her way, and tendeth her own busynesse.' ${ }^{17}$

A century later, John Spencer's Kaina kai palaia: things new and old (I658) similarly commended Rebecca for her industry. In his compendium of moral sayings and lessons, Spencer proposed that children should be set to honest employment as the patriarchs had 'their tender daughters brought up in doing Houshold business. Rebecca went with her pitcher on her shoulders to give drink to her Father's camels.' He further postulated that 'such was the harmless simplicity of those days, and such was the obedience of children that even she that was appointed to be the Mother of Patriarchs, Prophets and Kings refused not to set her hand to ordinary employments' ${ }^{18}$ According to Spencer, the young women of the day were not interested in following Rebecca's example of fetching water, but they preferred to use her story to justify the wearing of bracelets and jewellery on the ground that Eliezer had given Rebecca such gifts. ${ }^{19}$

This example of Rebecca as a noble figure who was not afraid to perform tasks beneath her station was also used by John Potter, later archbishop of Canterbury. In his Antiquities of Ancient Greece (I699), Potter praised the women of 'the primitive Ages' who were 'accustomed to draw Water, to keep sheep, and feed cows or horses'. He compared Rebecca who 'carry'd a pitcher and drew Water' with the 'rich and noble [from centuries past] who were taken up

for all the $[\mathrm{m}]$, that entend to line quietly and godlye in the Christen state of holy wedlock newly set forthe in English by Theodore Basille, transl. M. Coverdale and T. Basile (London, 1542), xliiii. Basile has been identified as Thomas Becon, since the preface in this work is identical to the one among Becon's published works: see The workes of Thomas Becon: whiche he hath hytherto made and published, with diuerse other newe bookes added to the same, heretofore nener set forth in print dituded into thre tomes or parts diligently perised, corrected, and amended: and now finished this present of our Lord (London, 1564).

17 Ibid.

18 John Spencer, Kaina Kai Palaia: Things New and Old, or A Storehouse of Similies, Sentences, Allegories, Apophthegms, Adagies, Apologues, Divine, Morall, Political, EC. With Their Several Applications (London, 1658 ), 482.

19 Ibid. 
with employments of inferior quality'. ${ }^{20}$ Potter was reputed to have disinherited his eldest son John for marrying a domestic servant, so perhaps his discourse of work and industry was tempered by an opinion about what kind of labour was acceptable for a person's station in life. ${ }^{21}$ Drawing water was not the hard toil that was associated with the 'work' of the labouring classes. ${ }^{22}$ Instead it was a dignified task that demonstrated a lack of idleness.

It is not coincidental that the word used most frequently by seventeenth-century women to refer to needlework was 'work'. The equation of needlework with industry is also evident from the frontispiece of a seventeenth-century pattern book which in its twelfth edition depicted the three figures of Wisdom, Industry and Folly. Industry is shown sitting under Wisdom's guidance and she is stitching. The book's subtitle reiterates the implications: $A$ New Booke wherin are divers Admirable Workes urought with the Needle. Newly invented and cut in Copper for the pleasure and profit of the Industrious. ${ }^{23}$ Lena Cowen Orlin has traced references to needlework in Shakespeare and concluded that needlework was a way in which women could appear intentionally busy. ${ }^{24}$ Those who practised needlework were praised not only for being industrious but also for avoiding idleness. Thus the subtext of a concern with industry appears to be contempt for idleness.

The prominent warnings about vanity and idle behaviour in literature directed to young women were also conveyed through the mermaid and looking glass motif in needlework. This motif has been located on some of the pieces illustrating the Rebecca narrative. It was especially prevalent in the seventeenth century as a warning against the folly of spending too much time in front of the mirror. There is some irony here since it was customary in the latter half of the seventeenth century for the embroidered boxes

20 John Potter, Archacologiae graecae: or, The antiquities of Greete (London, I699), 341.

21 ODNB, s.n. 'Potter, John (1673/4-1747)', online at: <http://www.oxforddnb. com/view/article/22612>, accessed September 2012.

22 Ruth B. Bottigheimer, The Bible for Children: from the Age of Gutenberg to the Presen (New Haven, CT, 1996), 94-6.

23 Frontispiece in John Taylor, The Needles Excellency. A New Booke wherin are divers Admirable Workes urought with the Needle. Newly invented and at in Copper for the pleasure and profit of the Industrious (London, 1631).

24 Lena Cowen Orlin, 'Three Ways to be Invisible in the Renaissance: Sex, Reputation, and Stitchery', in Patricia Fumerton and Simon Hunt, eds, Renaissante Culture and the Everyday (Philadelphia, PA, 1999), 183-203. 
to contain mirrors. The external decoration could be seen as a warning against the dangers within the box. ${ }^{25}$

The virtue of industry was an appropriate lesson for young women who belonged to middle- or upper-class households where idleness was a more pressing concern. Lady Anne Halkett made the connection between needlework and idleness explicit. In her autobiography, she praised her mother for the quality of her education and for ensuring that she and her sisters had had the kind of education that prevented idleness, and described how her mother 'kept a gentlewoman to teach us all kinds of needleworke, which shews I was not brought up in an idle life'. ${ }^{26}$ Depicting Rebecca's willingness to serve could have accentuated her lack of idleness. As a model for the household, Rebecca may have stood as an antitype of sloth.

Thus far the imagery has been used alongside the literature to suggest that Rebecca was important for her display of industry and her aversion to idleness. The second section of this essay will examine a needlework project recently acquired by the Museum of Lancashire. This embroidered cabinet remained in family hands for over four hundred years until very recently; it was therefore unknown to twentieth-century art collectors and scholars. ${ }^{27}$ The needlework of Eunice, the wife of Thomas Bourne of Nether Wyresdale, Lancashire, provides interesting examples of how Rebecca could be understood not only for herself, but as being like Mary. It also suggests that some women perceived modesty and industry differently from the instruction they received from sermons and printed texts.

In the I660s, Eunice embroidered five scenes for her cabinet. She chose the sacrifice of Isaac (Gen. 22) for the back panel, which formed the backdrop to the other scenes with Rebecca (Fig. 2). On the front panel she depicted Abraham sending out Eliezer (Fig. 3). The top panel was the iconic well scene (Fig. 4). The other two scenes were also common in the iconography of

${ }_{25}$ The best example is Port Sunlight, Lady Lever Art Gallery, LL5258, which has the mermaid motif on the lid of the embroidered box containing images of Rebecca: Xanthe Brooke, The Lady Lever Art Gallery Catalogue of Embroideries (Stroud, 1992), I 83.

${ }_{26}$ The Autobiography of Ame, Lady Halkett, ed. John Gough Nichols (London, 1875), 3, quoted in Geuter, 'Women and Embroidery', 173.

27 The embroidered cabinet (LANMS.2005.4) is currently at the Museum of Lancashire, Preston. Through correspondence with the museum, the Netherhampton Salerooms and Mrs Rachel Kent (née Bourne), provenance details have been established, although lack of historical records has so far made it impossible to identify or date Eunice Bourne with certainty. 


\section{AMANDA PULLAN}

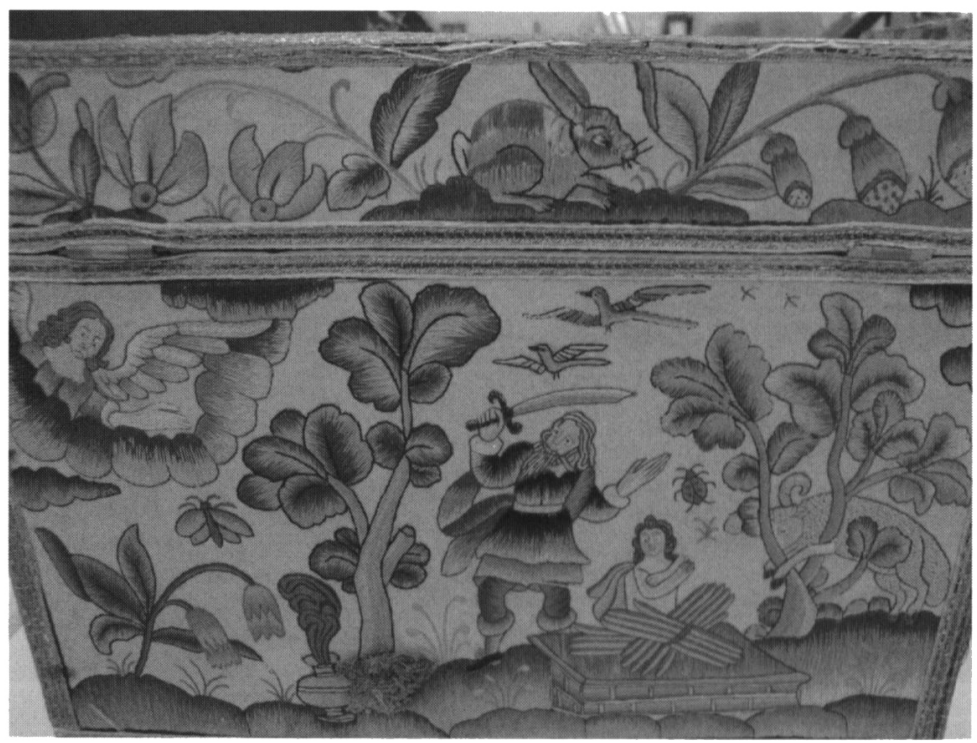

Fig. 2: Sacrifice of Isaac, Bourne cabinet. Museum of Lancashire, Preston. Photographs of figs $2-6$ by the author, and reproduced by courtesy of Lancashire County Council's Museum Service.

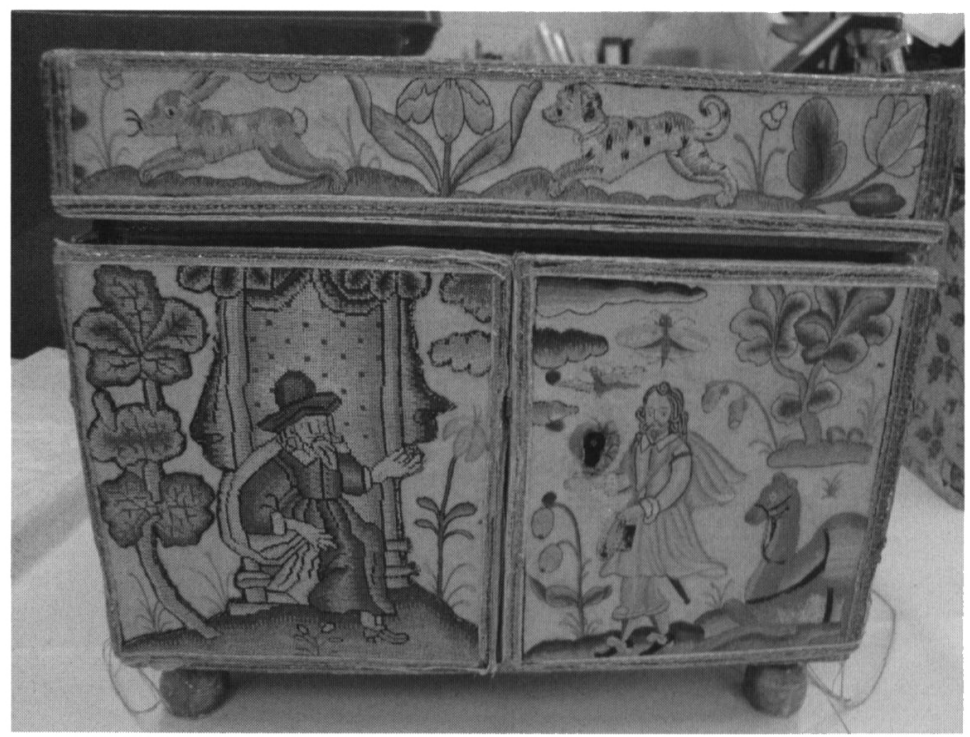

Fig. 3: Abraham sending Eliezer, Bourne cabinet. 


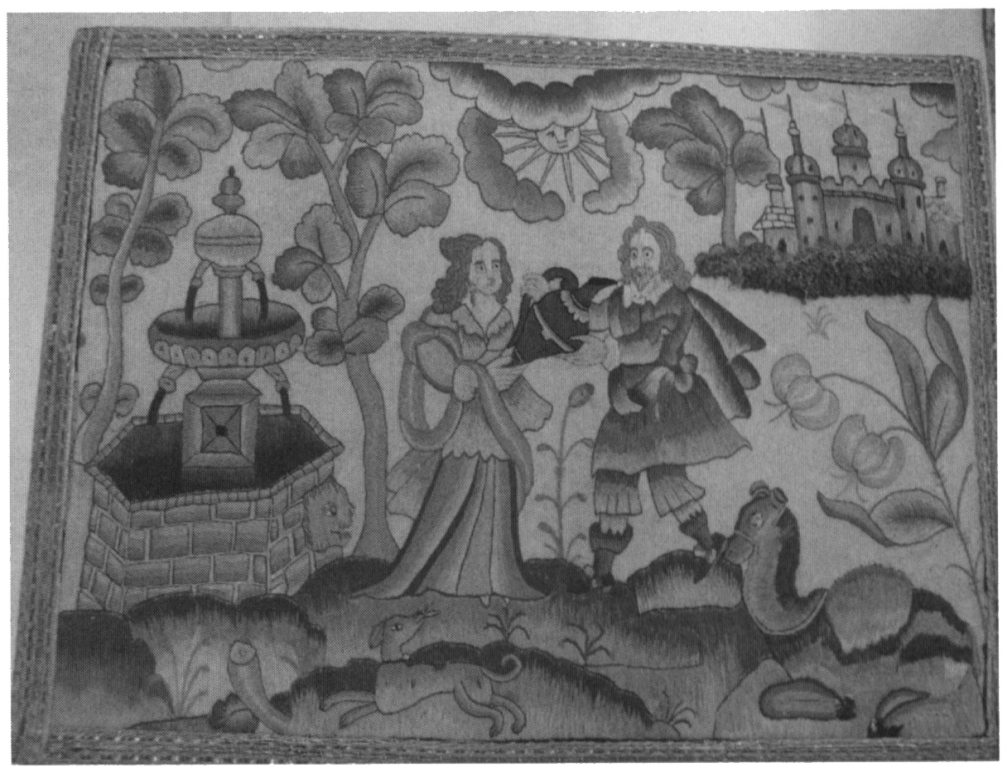

Fig. 4: Rebecca and Eliezer at the well, Bourne cabinet.

Rebecca: Rebecca and Eliezer travelling, and the meeting of Isaac and Rebecca. Significantly, however, when it came to the travelling scene, the strong likeness of the depiction of Rebecca to depictions of the Virgin Mary, intensified by her blue gown and the presence of the donkey, are compelling evidence that Eunice here elided the figures of Rebecca and Eliezer with those of Mary and Joseph (Fig. 5). This is particularly interesting because in the surviving embroideries it is highly unusual to represent a scene from the life of Christ as a replacement for a standard trope; ${ }^{28}$ indeed, it is uncommon to find any event outside the book of Genesis portrayed in the context of the story of Rebecca, let alone a scene from the New Testament. Moreover, it would be strange for an embroiderer to include all the other scenes from the Rebecca narrative, as Eunice has done, and yet replace one by a New Testament scene, unless she saw a connection between the narratives. Eunice's substitution suggests that she was reading

28 From my analysis of 150 seventeenth-century embroideries, this is the only example in which a scene from the life of Christ has been integrated within the story of Rebecca. 


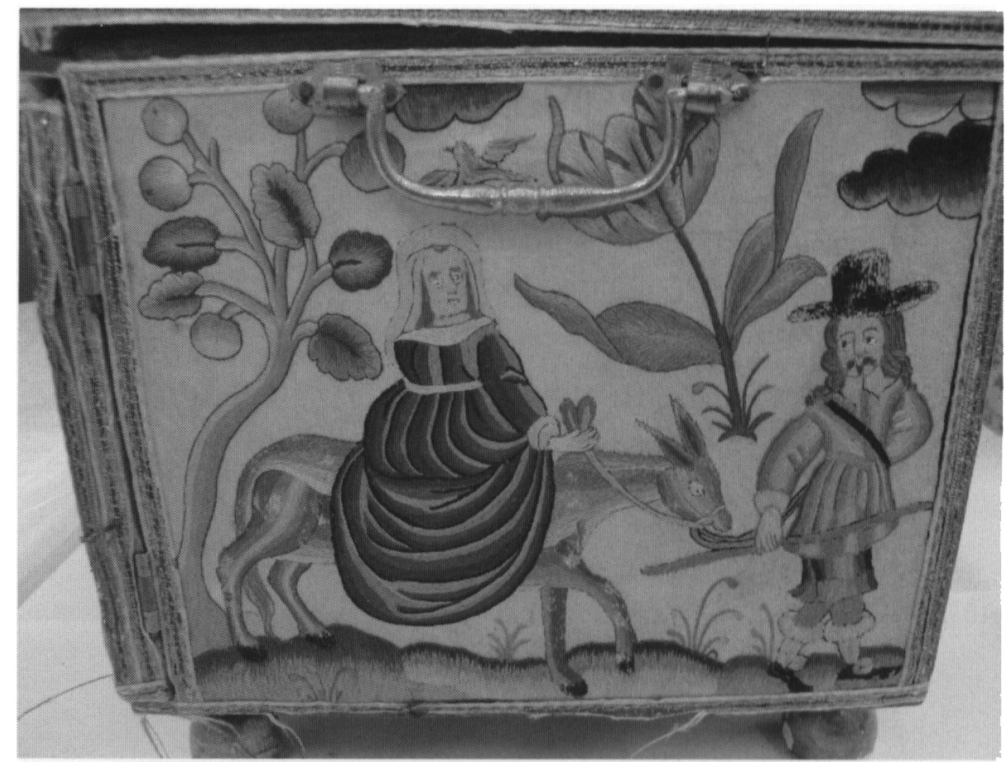

Fig. 5: Travelling scene with Rebecca and Eliezer portrayed as Mary and Joseph, Bourne cabinet.

Rebecca's story typologically, and replacing the Genesis scene with its equivalent in the New Testament. By portraying Rebecca as a Marian figure, it is evident that for Eunice the figure of Rebecca held typological significance. Before Mary, Rebecca had borne children from whom the Messianic line extended.

The reasons for Eunice's substitution are not entirely clear. The substitution of Mary and Joseph is too unusual for it to have been a 'recycling' of the scene from another project, especially since there are no known existing examples of a 'travelling Mary and Joseph' scene. Instead, it is possible that Eunice was Catholic. Unfortunately, neither Eunice nor her husband Thomas can be identified in the extant parish registers for the period. However, parish records do show that four members of the Bourne family refused to take the Protestant Oath of I64I, intended to demonstrate their allegiance to the 'true reformed Protestant religion against Popery and Popish Innovations'. A Thomas was one of those named. ${ }^{29}$ It

2. Henry J. Fishwicke, The History of the Parish of Garstang in the Connty of Lancaster (London, 1879), 264-72. 
was common for Roman Catholics to abstain from this oath, and their suspect political identity could shed some light on the design and contents of the casket. Eunice's cabinet has a secret drawer, and it also has a smaller container with a false bottom containing an embroidered ovoid reputed to be an acorn from the famed Boscobel Oak. The presence of this royalist relic suggests that the cabinet's maker was loyal to the Stuart crown and quite possibly to the Catholic religion. This seems more probable when considering Eunice's incorporation of Marian typology.

Tantalizingly little is known about Eunice, but her own circumstances may have affected the way she portrayed Rebecca. Her depiction of Rebecca is evidence of the 'domestic subversion' that Alexandra Walsham has recognized as a vital strand of the dynamics at play in the early modern household. ${ }^{30}$ Eunice's Rebecca calls into question the behaviour commonly ascribed to her in sermons on marriage. For example, in a sermon printed in 1630 , William Gouge pointed to Rebecca as an example of outward reverence. ${ }^{31}$ In line with his stated intention to 'stir up Christians to walk worthy of their vocation', Rebecca was offered as a model of female vocation, namely marriage. Gouge emphasized 'outward carriage', which he defined as 'sober behaviour, courteous gesture, and modest attire', and asserted that Rebecca had this kind of 'reverent carriage' because when she approached Isaac for the first time, she covered herself with a veil..$^{32}$ On the importance of female modesty, Gouge was not alone in his views. Gervase Markham introduced similar criteria for an ideal wife in his The English Housewife, including a section on temperance in behaviour and carriage, and another on garments and modest attire ${ }^{33}$

With this in mind, Eunice's depiction of the scene in which Rebecca meets Isaac, on the side panel of the casket, is particularly interesting. It shows a curious lack of sober behaviour. No veil is in sight. Instead, Rebecca appears to be seducing Isaac (Fig. 6). Rebecca is lifting her skirt and beckoning with her finger, offering

30 See, in this volume, Alexandra Walsham, "Holy Families: The Spiritualization of the Early Modern Household Revisited', 122-60.

${ }^{31}$ William Gouge, An Exposition of part of the Fift and Sixt chapters of S. Paules Epistle to the Ephesians (London, 1630), 21.

32 Ibid.

33 Gervase Markham, The English Houseuife, ed. Michael R. Best (Montreal, QC, 1986), 7-8. 


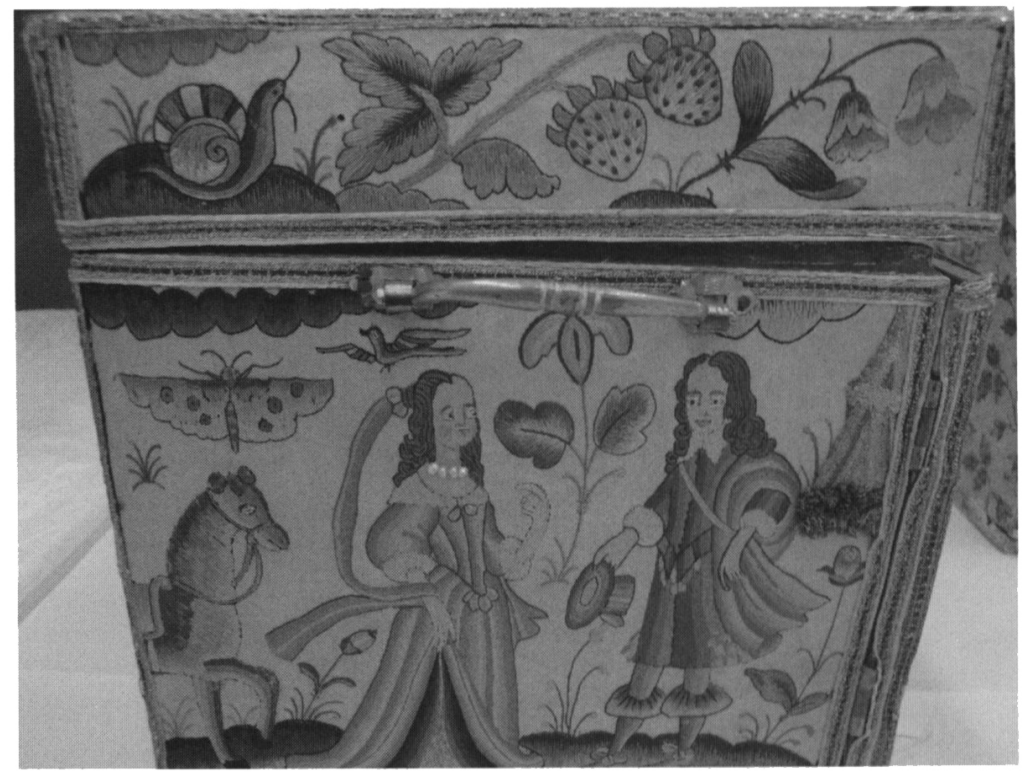

Fig. 6: Rebecca meeting Isaac, Bourne cabinet.

an explicit indication as to what comes next. Sexual activity was not an unusual association with the account of Rebecca, but it was not often displayed in needlework. Genesis 26: 8-9 tells how Abimelech, king of the Philistines, observed Isaac sporting with Rebecca, realized that she was his wife and forbade his men to sleep with her. As ministers in the seventeenth century strained to find direct applications of this biblical tale, it was clear they did not find fault with sexual play itself but rather the manner of it. ${ }^{34}$ The key difference found in Eunice's needlework is that Rebecca was the one initiating the 'sporting'. This was not sober behaviour according to Gouge, who stipulated:

Sobriety, as it is a vertue especially belonging to all women, so most especially to wives; and it is opposed to Levity and Wantonnesse ... This is not opposed to Matrimoniall familiarity: such as was between Isaac and Rebecca, Gen 26: 8, but such sporting ought ... to be in private, when they are alone.

34 Robert Cleaver and John Dod, $A$ godly forme of howshold government for the ordering of prinate families, according to the direction of God's word (London, 1621), sig. M2. 


\section{Needlework and Moral Instruction}

It ought to be begun by the husband, as it is there said that (Isaac) sported with Rebecca. ${ }^{35}$

Eunice's Rebecca provides an alternative message of wifely conduct, one that highlights Rebecca's role as a matriarch. The panel which seems problematic, Rebecca seducing Isaac, and which initially caused a museum curator to misattribute it as a scene depicting Solomon and the queen of Sheba, deepens our understanding of how virtue was taught to (and perhaps by) early modern women. Sexual relations for the purpose of carrying on a dynasty were exactly what was considered virtuous. This was particularly true in Rebecca's case, as her sexual relationships would lead to the building of a nation and the birth of Christ. That Eunice also embroidered a pomegranate in the travelling scene is also telling. Representing rebirth and fertility, the pomegranate is a prelude to the action in the final panel, the meeting of the two, and the consequent consummation of the marriage. Eunice's decision to use a motif of strawberries to decorate the top slip sends a similar message (Fig. 6). Strawberries, with their numerous seeds visible on the outside, were emblems of fertility, and could be another reference not only to Rebecca's fecundity but to the Virgin Mary and the birth of Christ. ${ }^{66}$ The symbolism of the seed is evident in Thomas Bentley's Monument of Matrons, which tells how Rebecca's parents gave her a blessing that she would 'grow into thousands and thy seed possess the gate of thine enemies and be victorious over them ... which was afterward fullye accomplished in Jesus Christ' ${ }^{37}$ For Eunice, the ideal of dynastic achievement appears to have become a reality. Burke's Peerage records that she bore three children who between them continued the Bourne family line for four centuries. ${ }^{38}$

To return to the main question driving this essay, we can see why Rebecca, as a model of female virtue, would have resonated with the seventeenth-century household. Rebecca's identifiably virtuous conduct in giving water to Abraham's servant was espe-

35 Gouge, Exposition, 21.

36 Susan Frye, Pens and Needles: Women's Textualities in Early Modern England (Philadelphia, PA, 2010), I72.

37 T[homas] B[entley], The Sixt Lampe of Virginitic: conteining a Mirrour for Maidens and Matrons (London, I582), 224.

${ }_{38}$ Bernard Burke, $A$ Genealogical and Heraldic History of the Landed Gentry of Great Britain and Ireland, 2 vols (London, 1871), 1: 130. 


\section{AMANDA PULLAN}

cially pertinent for young women who were being trained to run a household. This visual narrative provided instruction on the virtue of industry and the vice of sloth. But beyond this traditional message, which is echoed in contemporary literature, we see that the scene between Rebecca and Eliezer had heightened appeal since it represented the aspirations of unmarried women. Rebecca's story was also a way to communicate their understanding of what kind of virtues were important for marriage. Eunice Bourne's representation of Rebecca has indicated that willingness to bear children was more important than the 'modesty' prescribed in conduct books and sermons. Finally, it is important that the Rebecca narrative reached across confessional divides and figured visibly in many seventeenth-century households.

Lancaster University 